\title{
AOHR
}

Selected Papers of \#AoIR2021:

The 22nd Annual Conference of the

Association of Internet Researchers

Virtual Event / 13-16 Oct 2021

\section{"IT LOOKS BETTER ON INSTAGRAM": NETWORKED PHOTOGRAPH AND PUBLIC ART IN MUMBAI}

\author{
Ketaki Savnal \\ University of East Anglia
}

\section{Introduction}

In this paper, I discuss networked photography practices and selfie cultures at the Kala Ghoda Arts Festival (KGAF) in Mumbai. I offer two key examples of how global digital visual cultures are translated in the urban Indian context, and the influence on the experience of contemporary art, the city and the resident.

The KGAF is organised over nine days in February each year, in the art district of Kala Ghoda. Built by the colonial government, the district became a primary site in the production of cosmopolitanism in the time after Independence. In 1999, in the decade of economic reforms that opened up India to global markets, the elite art world started the KGAF, as a way to invite the public into the site. The festival was also designed to ideologically resist the violent, communal actions of the Shiv Sena, a political party trying to erase the multicultural, secular nature of the migrant port city (Zitzewitz 2014).

Today, with the popularity of social networking sites (SNS), thousands of young visitors, armed with DSLR cameras and smartphones, are drawn to the street art section of the festival. The elite art world, that now has access to global markets, has distanced themselves from the festival (Zitzewitz 2014) and as a result, corporate brands, upcoming artists and students are offered the exhibition spaces. These new participants, who are familiar with the visual vocabulary of SNS, know how to extend the life of their installations online, beyond the nine days of the festival. Their installations include "Instagrammable" features, such as unique lighting, seating and mirrors, and are criticised by older artists and visitors for being mere "photobooths" or selfie backdrops. An artist trained at the prestigious JJ School of Art told me that the festival had turned into a "small gutter" and there was "nothing but a bad smell" left.

\section{Conceptual framework}

I challenge the elite art world's criticism of "selfie crowds" and the art catering to them, and instead think about how camera phone technologies "disrupt" hierarchical exhibition spaces. Following several Internet researchers, I approach the selfie and everyday networked photography as a form of self-expression, labour (Abidin 2016), locative media (Hess 2015), embodied socialisation (Frosh 2015) and a mode of photography that 
collapses binaries of subject/object, spectator/operator and curated image/curator (Frosh 2015, Senft and Baym 2015).

To examine how the desire for networked visibility alters ideas of space and place, object production and meaning making, I draw from research on social networking sites, algorithms, branding and the production of subjectivity (Lazzarato 2014, Carah and Shaul 2016, Brodermerkel and Carah 2016) and global Instagram cultures (Leaver, Highfield and Abidin 2019).

I follow Pinney (1997) in understanding photography as a medium of creative expression rather than documentation in India, and Appadurai (2000) in recognising the role of electronic media in the production of neighbourhoods and national identities in a palimpsestic, postcolonial and politically volatile city.

\section{Method}

In February 2020 I attended the festival as a resident, long-time visitor, and academic researcher. I took an ethnographic approach, conducting observational audiovisual recording in the exhibition areas and in-depth interviews with artists, curators and visitors. To participate in the physical-digital assemblage, I monitored social media tags and digital images, took images and videos on my phone camera and posted them on Instagram, and commented on some images from other visitors. This was also my attempt to engage in the same fragmentary, humourous and spontaneous mode as Instagram photography, and participate as a visitor as much as a researcher.

\section{Findings}

Space, place and identity:

The intent of the organisers, to democratise the locality through art exhibitions and cultural workshops, is instead achieved by YouTube and Instagram algorithms, influencers and vloggers. The visitors who are brought to the festival by SNS, are unaware of the historical significance of the locality in the production of Mumbai as a cosmopolitan city. They take selfies with installations communicating social messages, such as gender equality, as well as advertising banners for brands like Tinder, that coexist in the exhibition space. This fluidity between artistic and commercial backdrops in selfies shared online, indicates a rejection of tradition and a celebration of liberal, Western values of individual autonomy, limited by and enshrined within a neoliberal logic of commodification. This is in contrast with the original discourse of the festival that privileged collective values of the socialist nation state. In this way, Kala Ghoda as a postcolonial place is reinterpreted as a space for creative photography and the stage for the visual production of a global digital identity by residents of the city.

Object production, meaning making and collaboration:

The assemblage of installations, artists, attendees, curators, camera technologies and SNS, animate each other through the desire of networked visibility. The installations that 
are designed as Instagram "bait", invite visitors to form close, embodied relationships with the material elements, through the limited field of vision of their camera phones. In order to take photographs from unique perspectives, visitors often disrespect the implicit rules of the installations and damage them in the process. The artists respond by mending them every morning, with an understanding that the installations have not been received as objects of reflection, but as creative prompts that generate photographic responses. Instagram accounts of the installations are prominently displayed in concept notes, and artists share and re-share images they are tagged in on the festival days, even posing with the installations in similar ways. In this way, the exhibition space is turned from a hierarchy into a generative physical-digital assemblage, underscored by a sense of embodied interdependence and collaboration. It reminds me of the concept of jugalbandi from Indian classical music, which refers to a duet of different styles or instruments, and also describes my interaction with these moving sounds and visuals that I record, edit and analyse.

\section{References}

Abidin, C (2016) "Visibility labour". Media International Australia. Vol. 161(1):86-100.

Appadurai, A (1996) Modernity at Large. Minneapolis: University of Minnesotta Press.

Brodmerkel, S, N Carah (2016) Brand Machines, Sensory Media and Calculative Culture. Palgrave Macmillan UK.

Carah, N, M Shaul (2016) "Brands and Instagram". Mobile Media \& Communication, Vol. 4(1) 69-84.

Deleuze, G, F Guattari (1980) A Thousand Plateaus. Translated by Brian Massumi. Minneapolis: University of Minnesota Press.

Frosh, P (2015) “The Gestural Image”. International Journal of Communication 9 pp. 16071628.

Hess, A (2015) "The Selfie Assemblage". International Journal of Communication 9. pp. $1629-1646$.

Lazzarato, M (2014) Signs and Machines. Translated by Joshua David Jordan. Los Angeles: Semiotext(e).

Leaver T, T Highfield and C Abidin (2019) Instagram. London: Polity.

Pinney, C (1997) Camera Indica. Chicago: University of Chicago Press.

Pink, S (2013) Doing Visual Ethnography. London: SAGE Publications Ltd.

Senft, T and N Baym (2015) "What Does the Selfie Say? Investigating a Global Phenomenon”. International Journal of Communication 9. pp. 1588-1606. 